\title{
СОДЕРЖАНИЕ НЕКОТОРЫХ БИОЛОГИЧЕСКИ АКТИВНЫХ ВЕЩЕСТВ И ХИМИЧЕСКИХ ЭЛЕМЕНТОВ В ЛЕКАРСТВЕННОМ СЫРЬЕ Echinacea purpurea (L.) Мoench ПОД ВЛИЯНИЕМ ЭССЕНЦИАЛЬНОГО МИКРОЭЛЕМЕНТА Сu
}

\author{
Н.Н. ЖАРКОВА, В.В. СУХОЦКАЯ, Ю.И. ЕРМОХИН
}

Медь относится к жизненно важным эссенциальным элементам в метаболизме человека. Медь и ее соединения также играют значимую роль в физиологических процессах, протекающих в клетках растений: дыхании, фотосинтезе, углеводном и фосфорном обмене веществ, синтезе белка, восстановлении и фиксации азота. Особенно остро стоит вопрос о применении медных удобрений в связи с существованием биогеохимических провинций с дефицитом этого элемента в почве. Эхинацея пурпурная Echinacea purpurea (L.) Moench - один из самых продаваемых растительных лекарственных препаратов во многих развитых странах мира. Она получила широкое применение в медицине и ветеринарии в качестве иммунокорректора. Однако данные по влиянию микроэлементов на урожайность и содержание биологически активных веществ в лекарственном сырье эхинацеи пурпурной единичны. В проведенном нами исследовании впервые представлены результаты, подтверждающие роль медных удобрений в повышении содержания биологически активных веществ в лекарственном сырье эхинацеи пурпурной, а также в его обогащении отдельными микроэлементами. Цель работы - оценка влияния эссенциального микроэлемента (Сu) на накопление некоторых биологически активных веществ (дубильные вещества, каротин, витамин С) и двух химических элементов (цинка и меди) в лекарственном сырье эхинацеи пурпурной сорта Знахарь. Эксперименты проводили на территории опытного поля Омского ГАУ им. П.А. Столыпина (г. Омск) в условиях южной лесостепи Западной Сибири в мае-сентябре 2016-2018 годов. Мелкоделяночный опыт закладывали по следующей схеме: абсолютный контроль (без удобрений), N125 (фон), N125 + 0,25ПДК Си (2,3 кг д.в./га), N125 + 0,5ПДК Си (4,7 кг д.в./га), N125 + 0,75ПДК Cu (7,0 кг д.в./га), 125 + ПДК Сu (9,4 кг д.в./га). Почва опытного участка - лугово-черноземная, маломощная малогумусовая, среднесуглинистая с содержанием гумуса $5,2 \%$, нитратного азота - 10,0 мг/кг, подвижного фосфора -394 мг/кг, обменного калия -749 мг/кг, рНвод. 6,56,8. Содержание подвижной меди в почве составляло 0,3 мг/кг. Повторность опыта 4-кратная, последовательность вариантов - систематическая, в несколько ярусов, площадь делянок - $10 \mathrm{~m}^{2}$. В качестве удобрений использовали ацетат меди (СН3СОО)2Сu (32 \%), по фону вносили аммиачную селитру $(34,4 \%)$. Посадку культуры проводили в конще мая 2016 года. Эхинацею пурпурную высаживали по 24 растения на делянку, схема посадки $70 \times 60$ см. Удобрения вносили вручную, под перекопку, до посадки культуры с заделкой в почву на глубину 10-15 см, равномерно распределяя их по всей площади делянки. Растительные образцы отбирали по вариантам опыта в сентябре, в фазу массового цветения культуры. В лекарственном сырье эхинацеи пурпурной определяли содержание дубильных веществ, каротина, аскорбиновой кислоты. Содержание микроэлементов (медь, цинк) в измельченных до порошкового состояния пробах определяли атомно-абсорбционным методом. Нами установлено, что однократное внесение медных удобрений способствовало накоплению в лекарственном сырье дубильных веществ, аскорбиновой кислоты и каротина. В среднем за 3 года исследований содержание дубильных веществ достоверно $($ p $<0,05)$ повышалось до 16,6 мг\%, аскорбиновой кислоты - до 5,8 мг\%, каротина - до 51,2 мг/кг в сырье (траве) эхинацеи пурпурной. Максимальное накопление биологически активных веществ отмечали при внесении ацетата меди в дозе 9,4 кг д.в./га. Каждый 1 кг медных удобрений повышал содержание дубильных веществ на 0,51 мг\%, аскорбиновой кислоты - на 0,29 мг\%, каротина - на 2,56 мг/кг $(\mathbf{p}<0,05)$. Отмечена сильная связь $(r=0,98, p<0,05)$ между дозами медных удобрений и содержанием подвижных форм цинка и меди в лекарственном сырье. При внесении 1 кг меди на фоне N125 коэффициент интенсивности воздействия удобрений (b) на содержание подвижной меди и цинка в лекарственном сырье эхинацеи составил соответственно 0,23 и 1,15 мг/кг. Полученные нами уравнения и коэффициенты интенсивности действия b позволяют на практике разрабатывать систему применения микроэлементов на лугово-черноземных почвах для конкретных природноклиматических условий возделывания культуры.

Ключевые слова: Echinacea purpurea (L.) Moench, лугово-черноземная почва, эссенциальные микроэлементы, медь, цинк, биологически активные вещества, южная лесостепь, Западная Сибирь. 
По данным Всемирной организации здравоохранения (World Health Organization), лекарственные средства растительного происхождения составляют значительную часть рынка фарминдустрии. Более $80 \%$ населения мира все чаще используют лекарственные растения как основной источник медицинской помощи. Эта цифра включает в себя не только все возрастающее население Китая и Индии, но и многие развитые страны (1). Около 80 \% всех современных фармацевтических препаратов прямо или косвенно получают из растительных источников $(2,3)$. По прогнозам в ближайшие 10 лет использование фитопрепаратов на мировом рынке будет расти и достигнет $60 \%$ (4). Лекарственные растительные средства имеют ряд преимуществ: отсутствие побочных эффектов, низкая токсичность, доступность, комплексное воздействие на организм (противовоспалительное, антимикробное, спазмолитическое, болеутоляющее, антитоксическое) (5).

В основных земледельческих регионах Российской Федерации площади почв с низкой обеспеченностью подвижными формами микроэлементов (медь, цинк и др.) достигают 50-90 \% от обследованной территории $(6,7)$. Критическое содержание микроэлементов приводит к значительным потерям в растениеводстве. Решение этой проблемы возможно с помощью агрономического биообогащения сельскохозяйственных растений $(8,9)$, в том числе лекарственных культур, различными биоэлементами, например медью.

Медь относится к эссенциальным элементам наряду с железом, цинком, йодом, селеном (10). Она выступает кофактором многих ферментов (11). Медь и ее соединения играют значимую роль в физиологических процессах, протекающих в клетках растений, - дыхании, фотосинтезе, углеводном и фосфорном обмене, синтезе белка, восстановлении и фиксации азота $(12,13)$. Она положительно влияет на водный режим растений, их засухо- и морозоустойчивость, повышает стойкость растений по отношению к различным болезням. Медные удобрения увеличивают в растениеводческой продукции содержание сахара, жира, аскорбиновой кислоты, витамина А и витаминов группы В $(14,15)$.

Внесение эссенциальных микроэлементов способствует активации ферментативных процессов у лекарственных растений, что ведет к биосинтезу и накоплению биологически активных веществ, повышает ценные качества лекарственного сырья (16). При этом в растениях микроэлементы находятся в доступной, органически связанной форме, что повышает их усвоение. В растительном организме эссенциальные микроэлементы связываются с биологически активными веществами, что способствует усилению фармакологических эффектов (17).

Эхинацея пурпурная Echinacea purpurea (L.) Moench - один из самых продаваемых растительных лекарственных препаратов во многих развитых странах мира (18). Она получила широкое применение в медицине и ветеринарии в качестве иммунокорректора. Все органы растения содержат биологически активные вещества - витамины А и С, дубильные вещества, флавоноиды, эфирные масла, антоцианы и алкамиды (19-21). Фундаментальные и клинические исследования доказали противовирусный, противовоспалительный, антиоксидантный, антибактериальный и антимикотический эффекты эхинацеи пурпурной (22). Однако данные по влиянию микроэлементов на урожайность и содержание биологически активных веществ в лекарственном сырье $E$. purpurea единичны $(23,24)$.

В проведенном нами исследовании впервые представлены результаты, подтверждающие роль медных удобрений в повышении содержания 
биологически активных веществ в лекарственном сырье эхинацеи пурпурной, а также в его обогащении микроэлементами.

Цель работы - оценка влияния эссенциального микроэлемента $(\mathrm{Cu})$ на накопление некоторых биологически активных веществ (дубильные вещества, каротин, витамин С) и химических элементов (цинка и меди) в лекарственном сырье эхинацеи пурпурной.

Методика. Эксперименты проводили в условиях южной лесостепи Западной Сибири (опытное поле Омского ГАУ им. П.А. Столыпина, г. Омск) в мае-сентябре 2016-2018 годов с растениями Echinacea purpurea (L.) Moench сорта Знахарь.

Мелкоделяночный опыт закладывали по следующей схеме: абсолютный контроль (без удобрений), $\mathrm{N}_{125}$ (фон), $\mathrm{N}_{125}+$ 0,25ПДК Сu (2,3 кг д.в./га), $\mathrm{N}_{125}+$ 0,5ПДК Сu (4,7 кг д.в./га), N125 + 0,75ПДК Сu (7,0 кг д.в./га), N125 + ПДК $\mathrm{Cu}$ (9,4 кг д.в./га). Почва опытного участка - лугово-черноземная, маломощная малогумусовая, среднесуглинистая. Агрохимические показатели почвы определяли общепринятыми методами (25). В год закладки опыта в слое 0-30 см она содержала 5,2 \% гумуса (по Тюрину), 10,0 мг/кг нитратного азота (по А.Е. Кочергину), 394 мг/кг подвижного фосфора и 749 мг/кг обменного калия (по Ф.В. Чирикову), емкость поглощения -

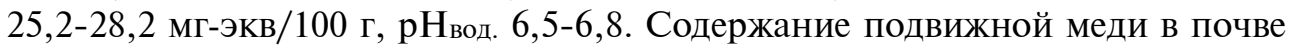
составляло 0,3 мг/кг. В связи с низким количеством $\mathrm{N}-\mathrm{NO}_{3}$ медь вносили на фоне $\mathrm{N}_{125}$, поскольку действие микроэлементов в полной мере проявляется только при сбалансированном макроэлементном питании. Дозы медных удобрений рассчитывали, исходя из ПДК $\mathrm{Cu}(3$ мг/кг) и содержания меди до посадки. Повторность опыта 4-кратная, последовательность вариантов - систематическая, в несколько ярусов. Площадь делянок - 10 м $^{2}$. В качестве удобрений использовали ацетат меди $\left(\mathrm{CH}_{3} \mathrm{COO}\right)_{2} \mathrm{Cu}(32 \%)$, по фону вносили аммиачную селитру $(34,4 \%)$.

Агротехника в опыте была общепринятой для условий зоны. Посадку проводили в конце мая 2016 года. Эхинацею пурпурную высаживали по 24 растения на делянку, схема посадки 70×60 см в целях создания оптимальной густоты 24 тыс. растений/га. Площадь питания одного растения при этом составляла 0,4 м². Удобрения вносили вручную, под перекопку, до посадки культуры с заделкой в почву на глубину 10-15 см, равномерно распределяя их по всей площади делянки.

Растительные образцы отбирали по вариантам опыта в сентябре в фазу массового цветения культуры. Для определения содержания биологически активных веществ использовали лекарственное сырье (трава), высушенное в тени в хорошо проветриваемых помещениях. Биохимические показатели рассчитывали на массу абсолютно сухого вещества. В лекарственном сырье эхинацеи пурпурной определяли содержание дубильных веществ по ГОСТ 24027.2-80 (26), каротина - по ГОСТ 13496.17-95 (27), аскорбиновой кислоты - по Мурри (28). Содержание микроэлементов (медь, цинк) в измельченных до порошкового состояния пробах определяли атомно-абсорбционным методом на спектрометре Varian AA-140 («Аквилон», Россия), по ГОСТ 30178-96 (29).

Для статистической обработки данных использовали стандартные пакеты компьютерных программ Microsoft Office Excel 2007 и STATISTICA 6.0 («StatSoft, Inc.», США). Рассчитывали средние значения (M) и стандартные ошибки средних $( \pm \mathrm{SEM})$, проводили регрессионный и корреляционный анализ. Различия считали статистически значимыми при $\mathrm{p}<0,05$. 
Для определения взаимосвязей между изучаемыми показателями рассчитывали коэффициенты корреляции $(r)$. Достоверными считали значения коэффициентов корреляции при $\mathrm{p}<0,05$.

Результаты. Микроэлементы способны повышать содержание витаминов и других биологически активных веществ в лекарственных растениях. Имеются данные об их положительном влиянии на синтез витаминов C, A, B1-12 (30, 31). В лекарственном сырье эхинацеи пурпурной, обогащенном медью, мы определили содержание дубильных веществ, аскорбиновой кислоты, каротина (табл. 1).

1. Содержание биологически активных веществ в лекарственном сырье эхинацеи пурпурной Echinacea purpurea (L.) Mоench в фазу цветения под влиянием различных доз медных удобрений $(n=24, M \pm \mathrm{SEM}$, г. Омск, 2016-2018 годы)

\begin{tabular}{l|c|c|c}
\hline \multicolumn{1}{c|}{ Вариант } & $\begin{array}{c}\text { Дубильные } \\
\text { вещества, мг\% }\end{array}$ & $\begin{array}{c}\text { Аскорбиновая } \\
\text { кислота, мг\% }\end{array}$ & Каротин, мг/кг \\
\hline Контроль (без удобрений) & $10,34 \pm 1,82$ & $2,11 \pm 1,12$ & $25,69 \pm 6,48$ \\
Фон (N125) & $11,76 \pm 1,02$ & $3,07 \pm 0,58$ & $27,65 \pm 5,38$ \\
Фон + 0,25ПДК Сu (2,3 кг д.в/га) & $13,07 \pm 0,28$ & $3,85 \pm 0,14$ & $32,31 \pm 2,74$ \\
Фон + 0,5 ПДК Сu (4,7 кг д.в/га) & $14,23 \pm 0,38$ & $4,54 \pm 0,25$ & $40,65 \pm 1,97$ \\
Фон + 0,75ПДК Сu (7,0 кг д.в/га) & $15,37 \pm 1,02$ & $5,18 \pm 0,61$ & $45,45 \pm 4,69$ \\
Фон + ПДК Сu (9,4 кг д.в/га) & $16,58 \pm 1,71$ & $5,84 \pm 0,99$ & $51,21 \pm 7,95$ \\
\cline { 1 - 2 }
\end{tabular}

П р и м е ч а н и е. Все различия между опытными и контрольным, а также фоновым вариантами статистически значимы при $\mathrm{p}<0,05$.

Дубильные вещества (дубильные кислоты, танины) - один из важных вторичных метаболитов в растительном организме. Они обеспечивают вяжущее, антибактериальное, антиэнзимное, противовоспалительное действие, а также защищают растения от млекопитающих и насекомых (32). По данным М.Н. Запрометова, в листьях эхинацеи пурпурной содержится до 7,2-10,2 \% дубильных веществ (33). В наших опытах этот показатель в среднем за годы исследований увеличивался с 13,07 до 16,58 мг\% в зависимости от внесенных доз ацетата меди. Максимальное содержание дубильных веществ (16,58 мг\%) наблюдалось при внесении 9,4 кг д.в./га меди. Различия в количестве дубильных веществ по всем вариантам опыта были достоверны (при р $<0,05)$ в сравнении как с контролем, так и с фоном.

R.G. Jr. Andrade c соавт. (34) отмечают хелатирующую способность танинов в отношении меди, что обусловливает их антиоксидантную активность. Положительное влияние меди также связано с тем, что она служит ключевым компонентом многих биологических соединений и играет важную роль в биосинтезе вторичных метаболитов, в том числе танинов (35). Полученные данные согласуются с сообщениями о том, что концентрации дубильных веществ напрямую зависят от количества питательных веществ, в частности $\mathrm{Cu}$ и $\mathrm{Mn}$, которые служат кофакторами ферментов, участвующих в разложении фенола и биосинтезе лигнина. У растений с дефицитом меди нарушается лигнификация (36).

2. Уравнения регрессии и коэффициенты корреляции между содержанием биологически активных веществ в лекарственном сырье эхинацеи пурпурной Echinacea purpurea (L.) Moench и вносимыми дозами медных удобрений (г. Омск, 2016-2018 годы)

\begin{tabular}{l|c|c}
\hline \multicolumn{1}{c|}{ В лекарственном сырье (х) } & Уравнение регрессии & Коэффициент корреляции $r$ \\
\hline Дубильные вещества & $\mathrm{y}=0,51 \mathrm{x}+11,82$ & $0,99(\mathrm{p}<0,05)$ \\
Аскорбиновая кислота & $\mathrm{y}=0,29 \mathrm{x}+3,13$ & $0,99(\mathrm{p}<0,05)$ \\
Каротин & $\mathrm{y}=2,56 \mathrm{x}+27,45$ & $0,99(\mathrm{p}<0,05)$ \\
\hline
\end{tabular}

Нами установлена высокая зависимость $(r=0,99$ при р $<0,05)$ между дозами медных удобрений и содержанием дубильных веществ (табл. 2). 
Коэффициент регрессии показывает, что при внесении ацетата меди в количестве 1 кг д.в./га содержание дубильных веществ повышалось на 0,51 мг\%.

Аскорбиновая кислота, или витамин С, относится к микронутриентам и служит незаменимым химическим соединением, которое участвует во многих процессах обмена веществ, выполняет антитоксическую и антиоксидантную функции, повышает сопротивляемость и защитные свойства организма. Для восполнения дефицита витамина С в настоящее время широко применяется искусственное обогащение им растениеводческой продукции и продуктов питания (37). Каротин играет значимую роль в фотосинтезе растений (фотозащитная, светособирающая, структурная), участвует в процессе роста и делении клеток, способствует активизации работы иммунной системы, помогает нормальному функционированию половых желез, влияет на рост, участвует в процессе зрительного восприятия, также это антиканцероген. Поступление провитамина А в организм происходит главным образом с растительной пищей, которая служит основным первоисточником каратиноидов (38).

В листьях эхинацеи пурпурной была обнаружена аскорбиновая кислота (39). В наших опытах расчетные дозы меди положительно сказались на накоплении витаминов в лекарственном сырье (см. табл. 1). Содержание аскорбиновой кислоты и каротина достоверно (p < 0,05) повышалось при увеличении доз ацетата меди. Количество витамина С варьировала в вариантах с медью от 3,85 до 5,84 мг\%, каротина - от 32,31 до 51,21 мг/кг. Максимальное содержание витаминов отмечали в варианте фон + ПДК Сu. Согласно сообщению V.B. Zagumennikov с соавт. (40), эхинацея пурпурная накапливает аскорбиновую кислоту в незначительном количестве, при этом подкормки и возраст растений оказывают несущественное влияние на содержание витамина С.

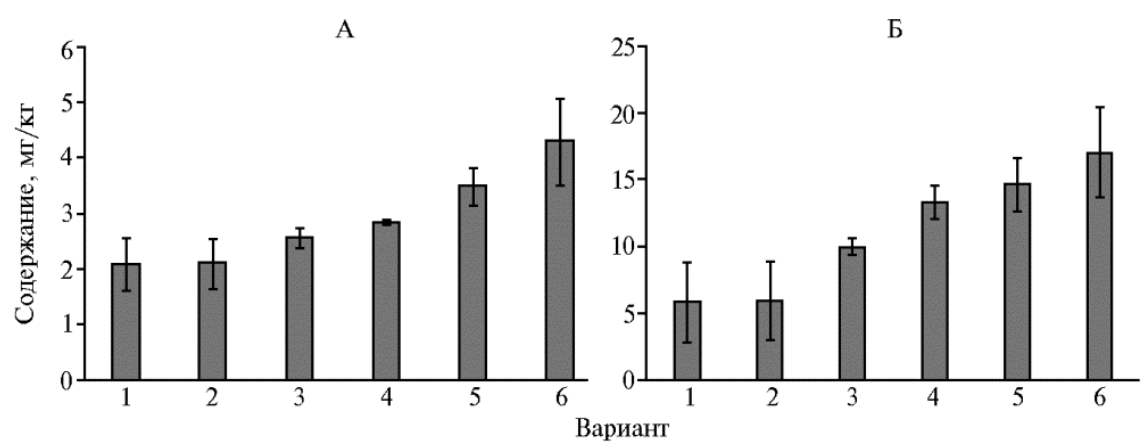

Содержание подвижных форм меди (А) и цинка (Б) в лекарственном сырье эхинацеи пурпурной Echinacea purpurea (L.) Moench в фазу цветения при внесении разных доз ацетата меди: 1 контроль (без удобрений), $2-\mathrm{N}_{125}$ (фон), 3 - N125 + 0,25ПДК Сu (2,3 кг д.в./га), $4-$ $\mathrm{N}_{125}+$ 0,5ПДК Сu (4,7 кг д.в./га), 5 - N125 + 0,75ПДК Сu (7,0 кг д.в./га), 5 - N125 + ПДК $\mathrm{Cu}(9,4$ кг д.в./га) $(n=24, M \pm S E M$, г. Омск, 2016-2018 годы).

Каждый 1 кг медных удобрений повышал содержание аскорбиновой кислоты на 0,29 мг\%, каротина - на 2,56 мг/кг (см. табл. 2). Корреляционный анализ указывал на очень сильную связь содержания витаминов с дозами меди $(r=0,99$ при р $<0,05)$.

Медь взаимодействует с различными химическими элементами, включая цинк, железо, молибден, серу, селен (41). Поэтому мы определяли содержание в лекарственном сырье эхинацеи пурпурной двух микроэлементов - цинка и меди (рис.).

Действие многих химических элементов может ингибировать или 
усиливать поступление других элементов, то есть быть либо синергетическим, либо антагонистическим (42). Вследствие этого в нашей работе было изучено влияние медных удобрений в системе почва-растение.

Содержание меди и цинка в надземной массе эхинацеи пурпурной имело четко выраженную линейную зависимость от доз вносимых в почву медных удобрений. Связи между различными дозами ацетата меди и количеством $\mathrm{Cu}$ и $\mathrm{Zn}$ в растениях в период цветения характеризовались уравнениями у $=0,23 \mathrm{Cu}+1,98(r=0,98$ при р $<0,05)$ и у $=1,15 \mathrm{Zn}+6,78$ $(r=0,98$ при р $<0,05)$. При внесении в 2016 году каждого килограмма меди в дозах 2,3; 4,7; 7,0 и 9,4 кг д.в. $\mathrm{Cu}$ /га на фоне $\mathrm{N}_{125}$ коэффициенты интенсивности воздействия медных удобрений (b) на содержание подвижных форм меди и цинка в лекарственном сырье эхинацеи составили соответственно 0,23 и 1,15 мг/кг. Для повышения содержания меди в лекарственном сырье на 1 мг/кг потребуется внести медных удобрений в количестве 4,3 кг $(r=0,98$ при р $<0,05)$. Полученные нормативные характеристики $\mathrm{b}$ (0,23 и 1,15 мг/кг) позволяют определить, как увеличатся количества доступных питательных элементов в лекарственном сырье при внесении микроудобрения. Многие авторы в своих работах также отмечали, что накопление меди в растениях повышалась с увеличением дозы применяемых медных удобрений (43-45).

Таким образом, внесение в почву ацетата меди на фоне макроудобрений позволило повысить содержание биологически активных веществ (дубильных веществ, витамина С и А) в лекарственном сырье эхинацеи пурпурной Echinacea purpurea (L.) Moench. Установлено, что внесение микроудобрений достоверно ( $<0,05)$ увеличивало содержание дубильных веществ до 16,58 мг\%, витамина С - до 5,84 мг\%, каротина - до 51,21 мг/кг. Применение микроудобрений также способствовало обогащению сырья микроэлементами (медью и цинком). Так, содержание меди в сырье эхинацеи увеличилось на 2,19 мг/кг по сравнению с фоном и составило 4,27 мг/кг ( $<$ 0,05). Наибольшая концентрация цинка составила 17,06 мг/кг, что на 11,17 мг/кг превышало значение в фоновом варианте. Полученные нами уравнения и коэффициенты интенсивности действия b позволят на практике разработать систему применения микроэлементов на лугово-черноземных почвах в условиях южной лесостепи Западной Сибири. Результаты наших экспериментов также дадут возможность расширить базы данных по биохимическому составу лекарственного сырья, выращиваемого при использовании медных удобрений.

\section{ФГБОУ ВО Омский государственный аграрный университет им. П.А. Столыпина, \\ Поступила в редакцию} 644008 Россия, г. Омск, Омская обл., Институтская пл., 1 , e-mail: nn.zharkova@omgau.org $\bowtie$, suhotskay-1990@mail.ru, yui.ermokhin@omgau.org

Sel'skokhozyaistvennaya biologiya [Agricultural Biology], 2020, V. 55, № 3, pp. 588-596

\section{ACCUMULATION OF BIOACTIVE SUBSTANCES AND CHEMICAL ELEMENTS IN Echinacea purpurea (L.) Moench MEDICINAL HERB AS INFLUENCED BY SOIL APPLICATION OF COPPER, AN ESSENTIAL MICROELEMENT}

\section{N.N. Zharkova, V.V. Sukhotskaya, Yu.I. Ermokhin}

Stolypin Omsk State Agrarian University, 1, Institutskaya pl., Omsk, 644008 Russia, e-mail nn.zharkova@omgau.org ( $₫$ corresponding author), suhotskay-1990@mail.ru, yui.ermokhin@omgau.org 


\section{Abstract}

Copper, an essential element in human metabolism, is a trace element for plants and animals. It plays a significant role in physiological processes (i.e. in photosynthesis, respiration, carbohydrate and protein metabolism), increases productivity, improves plant quality characteristics and increases resistance to adverse factors. A particular concern is the need to apply copper fertilizers in the biogeochemical provinces with $\mathrm{Cu}$ deficit in the soil. Echinacea purpurea (L.) Moench is one of the bestselling plant-based medicines in many developed countries around the world. It has been widely used in medicine and veterinary medicine for immunocorrection. However, publications on the effect of trace elements on the yield and content of biologically active substances in the medicinal raw materials of the E. purpurea are very few. Our study presents the results confirming the role of copper fertilizers in increasing the content of biologically active substances in the medicinal raw materials of E. purpurea, as well as in its enrichment with certain trace elements. The work aimed to assess the influence of essential microelement $(\mathrm{Cu})$ on the accumulation of certain biologically active substances (tanning substances, carotene, vitamin C) and chemical elements (zinc and copper) in the medicinal raw material of E. purpurea variety Znakhar. The plot tests were run in the conditions of the southern forest-steppe of Western Siberia (an experimental field of Omsk Stolypin State Agrarian University, Omsk, May-September 2016-2018). The experiment design was as follows: absolute control (without fertilizers), $\mathrm{N}_{125}$ (N-based fertilizer), $\mathrm{N}_{125}+0.25 \mathrm{MAC} \mathrm{Cu}$ (the maximum allowed concentration) $\left(2.3 \mathrm{~kg}\right.$ a.m./ha), $\mathrm{N}_{125}+0.5 \mathrm{MAC} \mathrm{Cu}(4.7 \mathrm{~kg}$ a.m./ha), $\mathrm{N}_{125}+0.75 \mathrm{MAC} \mathrm{Cu}(7.0 \mathrm{~kg}$ a.m./ha), N125 + $1 \mathrm{MAC} \mathrm{Cu}(9.4 \mathrm{~kg}$ a.m. $/$ ha $)$. The soil of the test site was meadow chernozem, low-power, low humus, medium loamy with a $5.2 \%$ humus content, $10.0 \mathrm{mg} / \mathrm{kg}$ nitrate nitrogen, $394 \mathrm{mg} / \mathrm{kg}$ mobile phosphorus, $749 \mathrm{mg} / \mathrm{kg}$ exchange potassium; $\mathrm{pH}$ 6.5-6.8. The mobile copper level in the soil was $0.3 \mathrm{mg} / \mathrm{kg}$. The experiment was arranged in four replicates, plots were systematically located in several tiers, with a plot size of $10 \mathrm{~m}^{2}$. Copper acetate $(\mathrm{CH} 3 \mathrm{COO})_{2} \mathrm{Cu}(32 \%)$ was used as $\mathrm{Cu}$ fertilizer, ammonium nitrate $(34.4 \%)$ was an $\mathrm{N}$-based fertilizer. The crop was planted at the end of May 2016, 24 plants per plot, with $70 \times 60 \mathrm{~cm}$ spacing. Fertilizers were manually incorporated into the soil to a $10-15 \mathrm{~cm}$ depth before planting (at tilling), and uniformly distributed throughout the entire plot area. Plants were collected in September, during E. purpurea mass flowering phase. Tannings, carotene, and ascorbic acid were quantified in the medicinal raw material of E. purpurea. The concentration of trace elements (copper, zinc) in powdered herb samples was determined by atomic absorption spectroscopy. We have found out that a single application of copper fertilizers contributed to accumulation of tanning substances, ascorbic acid and carotene in the herb raw material. On average, over three years of our research, the level of bioactive substances in the raw material (grass) increased reliably ( $\mathrm{p}<0.05$ ), to $16.6 \mathrm{mg} \%$ for tanning, to $5.8 \mathrm{mg} \%$ for ascorbic acid, and to $51.2 \mathrm{mg} / \mathrm{kg}$ for carotene. A copper acetate dose of $9.4 \mathrm{~kg} \mathrm{a.m}$./ha resulted in maximum concentration of the bioactive substances. Each $1 \mathrm{~kg} \mathrm{of} \mathrm{Cu}$ fertilizer increased the content of tannins by $0.51 \mathrm{mg} \%$, ascorbic acid by $0.29 \mathrm{mg} \%$, and carotene by $2.56 \mathrm{mg} / \mathrm{kg}(\mathrm{p}<0.05)$. Thus, the use of $\left(\mathrm{CH}_{3} \mathrm{COO}\right){ }_{2} \mathrm{Cu}$ contributes to an improved medicinal value of $E$. purpurea. The copper fertilizer dosages correlated tightly with the level of mobile zinc and copper in medicinal raw materials $(r=0.98, \mathrm{p}<0.05)$. Each $1 \mathrm{~kg}$ of copper added with N125 increased the content of mobile copper and zinc in E. purpurea raw material by 0.23 and $1.15 \mathrm{mg} / \mathrm{kg}$, respectively. These values are $\mathrm{b}$ coefficients that evaluate the effects of copper fertilizers and, together with the regression equations we obtained, allow practitioners to draw up protocols for applying micronutrient fertilizers in meadow chernozem soils at an early stage of $E$. purpurea plant development in specific growing conditions.

Keywords: Echinacea purpurea (L.) Moench, meadow chernozem soil, essential microelements, copper, zinc, bioactive substances, southern forest-steppe, Western Siberia.

\section{REFEREN CES}

1. Jamshidi-Kia F., Lorigooini Z., Amini-Khoei H. Medicinal plants: Past history and future perspective. Journal of Herbmed Pharmacology, 2018, 7(1): 1-7 (doi: 10.15171/jhp.2018.01).

2. Hariharan P., Subburaju T. Medicinal plants and its standardization - a global and industrial overview. Global Journal of Medicinal Plant Research, 2012, 1(1): 10-13.

3. Nirmal S.A., Pal S.C., Otimenyin S.O., Aye T., Elachouri M., Kundu S.K., Thandavarayan R.A., Mandal S.C. Contribution of herbal products global market. The Pharma Review, 2013: 95-104.

4. Bogoyavlenskii A.P., Aleksyuk P.G., Turmagambetova A.S., Berezin V.E. Farmatsevticheskie 
nauki, 2013, 6(5): 1184-1187 (in Russ.).

5. Ekor M. The growing use of herbal medicines: issues relating to adverse reactions and challenges in monitoring safety. Frontiers in Pharmacology, 2013, 4: 177 (doi: 10.3389/fphar.2013.00177).

6. Kabata-Pendias A., Pendias H. Trace elements in soils and plants. CRC Press, Boca Raton, London, New York, Washington, D.C., 2001.

7. Aristarkhov A.N., Bushuev N.N., Safronova K.G. Agrokhimiya, 2012, 9: 26-40 (in Russ.).

8. Dimpka C.O., Bindraban P. Fortification on micronutrients for efficient agronomic production: a review. Agronomy for Sustainable Development, 2016, 36: 1-26 (doi: 10.1007/s13593015-0346-6).

9. Valença A.W., Bake A., Brouwer I.D., Giller K.E. Agronomic biofortification of crops to fight hidden hunger in sub-Saharan Africa author links open overlay panel. Global Food Security, 2017, 12: 8-14 (doi: 10.1016/j.gfs.2016.12.001).

10. Vavoulidou E.E., Avramides E.J., Papadopoulos P., Dimirkou A.T., Charoulis A., Konstantinidou-Doltsinis S. Copper content in agricultural soils related to cropping systems in different regions of Greece. Communications in Soil Science and Plant Analysis, 2005, 36(4-6): 759-773 (doi: 10.1081/CSS-200043367).

11. Pavelkova M., Vysloužil J., Kubova K., Vetchy D. Biological role of copper as an essential trace element in the human organism. Czech and Slovak Pharmacy, 2018, 67(4): 143-153.

12. Broadley M., Brown P., Buerkert A., Camak I., Cooper J., Eichert T., Engels C., Fernandez V., Kirkby T., Eckhard G., Hawkesford M., Horst W., Huber D., Kichey T., Ludwi B., Jian Feng Ma., Marschner P., Neumann E., Neumann G., Schlecht H., Rengel Z., Romheld V., Schjoerring J., Moller I.S., Weinmann M., White P., Wiesler F., Zhao F. Marschner's mineral nutrition of higher plants. Elsevier Ltd., 2012 (doi: 10.1016/B978-0-12-384905-2.00025-X).

13. Braz J. Copper in plants. Brazilian Journal of Plant Physiology, 2005, 17(1): 145-156 (doi: 10.1590/S1677-04202005000100012).

14. Burkhead J.L., Gogolin Reynolds K.A., Abdel-Ghany S.E., Cohu C.M., Pilon M. Copper homeostasis. New Phytologist, 2009, 182(4): 799-816 (doi: 10.1111/j.1469-8137.2009.02846.x).

15. Printz B., Lutts S., Hausman J.-F., Sergeant K. Copper trafficking in plants and its implication on cell wall dynamics. Frontiers in Plant Science, 2016, 7: 601 (doi: 10.3389/fpls.2016.00601).

16. Makarova V.G., Laksaeva E.A., Martynov E.G. Rossiiskii mediko-biologicheskii vestnik imeni akademika I.P. Pavlova, 2006, 3: 29-35 (in Russ.).

17. Krasnov E.A., Savel'eva E.E., Ryzhakova N.K., Reshetov Ya.E., Gataullina A.R. Khimiya rastitel'nogo syr'ya, 2017, 4: 145-151 (doi: 10.14258/jcprm.2017041934) (in Russ.).

18. Nonvitamin and nonmineral nutritional supplements. S.M. Nabavi, A.S. Silva (eds.). Academic Press, 2019 (doi: 10.1016/C2016-0-03546-5).

19. Sharifi-Rad M., Mnayer D., Morais-Braga M.F.B., Carneiro J.N.P., Bezerra C.F., Coutinho H.D.M., Salehi B., Martorell M., del Mar Contreras M., Soltani-Nejad A., Uribe Y.A.H., Yousaf Z., Iriti M., Sharifi-Rad J. Echinacea plants as antioxidant and antibacterial agents: From traditional medicine to biotechnological applications. Phytotherapy Research, 2018, 32(9): 1653-1663 (doi: 10.1002/ptr.6101).

20. Kumar R.M., Ramaiah S. Pharmacological importance of Echinacea purpurea. International Journal of Pharma and Bio Sciences, 2011, 2(4): 304-314.

21. Shekarchi M., Hajimedipoor H., Khanavi M., Rustaie A. The effects of plant age and harvesting time on chicoric and caftaric acids content of E. purpurea (L.) Moench. Iranian Journal of Pharmaceutical Sciences, 2012, 8(3): 203-208.

22. Khasina E.I. Izvestiya Samarskogo nauchnogo tsentra Rossiiskoi akademii nauk, 2014, 16(5-2): 1030-1032 (in Russ.).

23. Babaeva E.Yu. Osobennosti mineral'nogo pitaniya ekhinatsei purpurnoi v usloviyakh Nechernozemnoi zony RF. Avtoreferat kandidatskoi dissertatsii [Features of the Echinacea purpurea mineral nutrition in the Non-chernozem zone of the Russian Federation. PhD Thesis]. Moscow, 2000 (in Russ.).

24. Hajagha R., Kirici S., Tabrizi L., Asgharzadeh A., Hamidi A. Evaluation of growth and yield of purple coneflower (Echinacea purpurea 1.) in response to biological and chemical fertilizers. Journal of Agricultural Science, 2017, 9(3): 160-171 (doi: 10.5539/jas.v9n3p160).

25. Agrokhimicheskie metody issledovaniya pochv /Pod redaktsiei A.V. Sokolova [Agrochemical methods in soil research. A.V. Sokolov (ed.)]. Moscow, 1975 (in Russ.).

26. GOST 24027.2-80 Syr'e lekarstvennoe rastitel'noe. Metody opredeleniya vlazhnosti, soderzhaniya zoly, ekstraktivnykh i dubil'nykh veshchestv, efirnogo masla [GOST 24027.2-80 Raw medicinal vegetable. Methods for determination of moisture, ash content, extractive compounds and tannins, essential oils]. Moscow, 1999 (in Russ.).

27. GOST 13496.17-95 Korma. Metody opredeleniya karotina [GOST 13496.17-95 Feed. Methods for determining carotene]. Moscow, 2011 (in Russ.).

28. Mineev V.G., Sychev V.G., Amel'yanchik O.A., Bolysheva T.N., Gomonova N.F., Durynina E.P., Egorov V.S., Edemskaya N.L., Karpova E.A., Prizhukova V.G. Praktikum po agrokhimii /Pod redaktsiei V.G. Mineeva [Workshop on agrochemistry. V.G. Mineev (ed.)]. Moscow, 2001 (in Russ.). 
29. GOST 30178-96 Syr'e i produkty pishchevye. Atomno-absorbtsionnyi metod opredeleniya toksichnykh elementov [GOST 30178-96 Raw materials and food products. Atomic absorption method for determination of toxic elements]. Moscow, 1997 (in Russ.).

30. Collins J.F., Klevay L.M. Copper. Advances in Nutrition, 2011, 2(6): 520-522 (doi: 10.3945/an.111.001222).

31. Kaiser C., Wernery U., Kinne J., Marker L., Liesegang A. The role of copper and vitamin A deficiencies leading to neurological signs in captive cheetahs (Acinonyx jubatus) and lions (Panthera leo) in the United Arab Emirates. Food and Nutrition Sciences, 2014, 5(20): 1978-1990 (doi: 10.4236/fns.2014.520209).

32. Hassanpour S., Maheri-Sis N., Eshratkhah B., Mehmandar F.B. Plants and secondary metabolites (Tannins): a review. International Journal of Forest, Soil and Erosion, 2011, 1(1): 47-53.

33. Zaprometov M.N. Osnovy biokhimii fenol'nykh soedinenii [Fundamentals of biochemistry of phenolic compounds]. Moscow, 1974 (in Russ.).

34. Andrade R.G. Jr., Dalvi L.T., Silva J.M. Jr., Lopes G.K., Alonso A., Hermes-Lima M. The antioxidant effect of tannic acid on the in vitro copper-mediated formation of free radicals. $A r$ chives of Biochemistry and Biophysics, 2005, 437(1): 1-9 (doi: 10.1016/j.abb.2005.02.016).

35. Khathutshelo M.V., Mpumelelo N., Wonder N., Fhatuwani M.N. Effects of foliar spray application of selected micronutrients on the quality of bush tea. Horticultural Science, 2016, 51(7): 873879 (doi: 10.21273/hortsci.51.7.873).

36. Santos R.M., Fortes G.A.C., Ferri P.H., Santos S.C. Influence of foliar nutrients on phenol levels in leaves of Eugenia uniflora. Revista Brasileira de Farmacognosia, 2011, 21(4): 581-586 (doi: 10.1590/S0102-695X2011005000112).

37. Araya M.M., Pizarro F., Olivares M., Arredondo M., González M., Méndez M. Understanding copper homeostasis in humans and copper effects on health. Biological Research, 2006, 39(1): 183-187 (doi: 10.4067/S0716-97602006000100020).

38. Napoli J.L. Vitamin A. Biochemistry and physiological role. In: Encyclopedia of human nutrition (second edition). Elsevier, Berkeley, CA, 2005: 339-347 (doi: 10.1016/B0-12-226694-3/02280-8).

39. Mistríková I., Vaverková S. Echinacea - chemical composition, immunostimulatory activities and uses. Thaiszia - Journal of Botany, 2006, 16: 11-26.

40. Zagumennikov V.B., Molchanova A.V., Babaeva E.Yu., Petrova A.L. Accumulation of ascorbic acid in fresh Echinacea purpurea plants and their processing products. Pharmaceutical Chemistry Journal, 2015, 48(10): 671-674 (doi: 10.1007/s11094-015-1168-1).

41. Osredkar J., Sustar N. Copper and zinc, biological role and significance of copper/zinc imbalance. Journal of Clinical Toxicology, 2011, 3: 1-18 (doi: 10.4172/2161-0495.S3-001).

42. Wang Y., Ou Y.L., Liu Y.Q., Xie Q., Liu Q.F., Wu Q., Fan T.Q., Yan L.L., Wang J.Y. Correlations of trace element levels in the diet, blood, urine, and feces in the chinese male. Biological Trace Element Research, 2012, 145(2): 127-135 (doi: 10.1007/s12011-011-9177-8).

43. Kumar R., Mehrotra N.K., Nautiyal B.D., Kumar P., Singh P.K. Effect of copper on growth, yield and concentration of $\mathrm{Fe}, \mathrm{Mn}, \mathrm{Zn}$ and $\mathrm{Cu}$ in wheat plants (Triticum aestivum L.). Journal of Environmental Biology, 2009, 30(4): 485-488.

44. Kaewchangwat N., Dueansawang S., Tumcharern G., Suttisintong K. Synthesis of copper-chelates derived from amino acids and evaluation of their efficacy as copper source and growth stimulator for Lactuca sativa in nutrient solution culture. Journal of Agricultural and Food Chemistry, 2017, 65(45): 9828-9837 (doi: 10.1021/acs.jafc.7b03809).

45. Stepien A., Wojtkowiak K. Effect of foliar application of $\mathrm{Cu}, \mathrm{Zn}$, and $\mathrm{Mn}$ on yield and quality indicators of winter wheat grain. Chilean Journal of Agricultural Research, 2016, 76(2): 220-227 (doi: 10.4067/s0718-58392016000200012). 